\title{
ANALISIS KEUANGAN TERHADAP KELAYAKAN INVESTASI LABORATORIUM ANGIOGRAFI RUMAH SAKIT BETHESDA YOGYAKARTA
}

\author{
Cecilia Farrona Al Hadri ${ }^{1}$, Ari Natalia Probandari ${ }^{2}$, Rizaldi Taslim Pinzon ${ }^{3}$ \\ ${ }^{1}$ Program Pascasarjana Fakultas Kedokteran Universitas Gadjah Mada \\ Yogyakarta \\ 2Bagian Ilmu Kesehatan Masyarakat Fakultas Kedokteran Universitas Sebelas \\ Maret Surakarta \\ ${ }^{3}$ Fakultas Kedokteran Universitas Kristen Duta Wacana \\ Korespondensi: medidoc2002@yahoo.com
}

\begin{abstract}
ABSTRAK
Latar Belakan: kematian akibat PTM (Penyakit Tidak Menular) diperkirakan akan terus meningkat di seluruh dunia, peningkatan terbesar akan terjadi di negara-negara berkembang. Mempertahankan konsumen dan berusaha mendapatkan konsumen baru merupakan strategi wajib yang harus di jalankan oleh rumah sakit. Keberadaan konsumen sangat penting bagi bisnis rumah sakit karena konsumen merupakan roda bisnis rumah sakit. Rumah Sakit Bethesda Yogyakarta, berencana untuk melakukan investasi laboratorium Angiografi untuk menunjang fasilitas kesehatan yang sudah ada. Sebelum melakukan investasi penting untuk mengetahui berapa besar unit cost dan tarif yang akan ditetapkan selain itu juga perlu diketahui kemauan membayar (Willingness to Pay) dan kemampuan membayar (Ability to Pay) pasien terhadap penggunaan layanan.

Metode Penelitian: penelitian dilakukan dengan menggunakan rancangan studi kasus yang dilakukan di Rumah Sakit Bethesda Yogyakarta. Sebanyak 265 orang dipilih sebagai responden, yang diambil dari poliklinik saraf dan penyakit dalam. Data primer terdiri dari data kemauan dan kemampuan pasien untuk melakukan pelayanan laboratorium angiografi. Data sekunder di dapatkan dari rumah sakit, penelitian terdahulu dan lainnya. Analisis investasi dihitung menggunakan Net Present Value, Internal Ratr of Return, payback Period dan Return On Investment.

Hasil: Perhitungan dengan menggunakan analisis Net Present Value menghasilkan nilai sebesar Rp.23.569.363.711,-. Jika dibandingkan dengan nilai modal, NPV bernilai positif sehingga investasi ini layak dilaksanakan. Analisis Internal Rate of Return menghasilkan nilai 29\% yang berarti lebih besar dari faktor diskonto artinya dengan menggunakan analisis ini investasi juga layak dilakukan. Perhitungan menggunakan Payback Period diketahui masa balik modal investasi laboratorium angiografi adalah selama tiga tahun tujuh bulan dan Return On Invesment menunjukkan pelayanan laboratrium angiografi berkemampuan untuk menghasilkan laba sebesar $120 \%$.

Kesimpulan: hasil penelitian menunjukkan investasi laboratorium angiografi dari aspek keuangan layak dilakukan. Kemauan masyarakat untuk menggunakan layanan cukup tinggi namun dari segi kemampuan rata-rata masih rendah.
\end{abstract}

Kata Kunci: Laboratorium angiografi, investasi, NPV, IRR, Payback Period, ROI, WTP, ATP. 


\title{
FEASIBILITY STUDY OF ANGIOGRAPHY LABORATORY INVESTMENT IN BETHESDA HOSPITAL YOGYAKARTA
}

\author{
Cecilia Farrona Al Hadri ${ }^{1}$, Ari Natalia Probandari ${ }^{2}$, Rizaldi Taslim Pinzon ${ }^{3}$ \\ ${ }^{1}$ The Graduate School of Medical Faculty of Gadjah Mada University \\ Yogyakarta \\ 2Public Health Department Faculty of Medicine Sebelas Maret University \\ Surakarta \\ ${ }^{3}$ Duta Wacana Christian University School of Medicine \\ Corespondence: medidoc2002@yahoo.com
}

\begin{abstract}
Background: Mortalities caused by NCDs (non-communicable diseases) are predicted to continue rising throughout the world, especially at developing countries. Retaining patients and trying to get new patients are the required strategy to be done by the hospital. Patients are very important for the hospital business because the patients are the core of hospital business. Bethesda Hospital in Yogyakarta, planned to invest angiography laboratory to support the health facilities. Before investing, it is important to know how much the unit cost and tariffs to be set, but it is also necessary to know the WTP (willingness to pay) and the ability to pay (Ability to Pay) from patients to take services.

Methods: Research is done by using a case study design conducted at Bethesda Hospital in Yogyakarta. There are 265 people choosed as respondents from neurology and internal medicine clinic. Primary data consists of the patient's willingness and ability data to perform angiography laboratory services. Secondary data is got from the hospital, and other previous studies.

Result: The result of calculations that used Net Present Value analysis is Rp. Rp.23.569.363.711, - that has positive value of NPV compared to asset value. Internal Rate of Rreturn analysis obtain $29 \%$ of IRR value which means the value is greater than the discount factor. Payback Period would be obtained in four years and eleven months and Return On Invesment demonstrated the ability to generate a profit of $120 \%$.

Conclusion: The results showed angiography laboratory investments from the financial aspect is worth doing. Willingness of people to use the service is quite high. however, the ability to pay is still low.
\end{abstract}

Keywords: Laboratorium angiografi, investasi, NPV, IRR, Payback Period, ROI, WTP, ATP. 


\section{PENDAHULUAN}

Penyakit Tidak Menular (PTM) merupakan penyebab utama kematian secara global. Data World Health Organization (WHO) (2015), menunjukkan bahwa pada tahun 2012, dari 56 juta kematian yang terjadi di dunia, 38 juta atau hampir dua pertiganya disebabkan oleh PTM. Angka ini naik 60\% dari jumlah kematian di tahun 2000. Penyakit jantung dan pembuluh darah (Cardiovasculer) membunuh 17,5 juta orang, yang artinya 3 disetiap 10 kematian. 7,4 juta orang meninggal karena serangan jantung iskemik dan 6,7 juta meninggal karena serangan stroke. Kematian akibat PTM diperkirakan akan terus meningkat di seluruh dunia, peningkatan terbesar akan terjadi di negara-negara menengah dan miskin. Data Balitbangkes, pada tahun 2014 di Indonesia terjadi sekitar 41.590 kematian.

$$
\text { Era pasar bebas }
$$

mengharuskan setiap industri untuk bertahan dan berusaha berkembang. Industri rumah sakit menjadi salah satu industri yang mengalami perubahan dengan tingkat akselerasi cukup tinggi. Padahal, sebelum globalisasi merupakan sesuatu yang tabu bagi rumah sakit untuk beriklan (melakukan pemasaran). Rumah sakit dianggap kurang etis jika gencar menawarkan produknya. Dalam era perdagangan bebas peran dari manajemen pemasaran menjadi sangat vital dalam usaha mempertahankan keberadaan rumah sakit sehingga tetap mampu bersaing. Dalam hal ini rumah sakit harus mampu menerapkan strategi pengembangan dalam situasi mekanisme pasar sambil menjalankan misi sosialnya. ${ }^{1}$

Mempertahankan konsumen dan berusaha mendapatkan konsumen baru merupakan strategi wajib yang harus dijalankan oleh rumah sakit.
Konsep manajemen strategis yang dikembangkan saat ini ialah bagaimana sebuah perusahaan (rumah sakit) mampu membuat konsumen loyal terhadap produk yang ditawarkan, salah satu strategi yang dikembangkan ialah dengan membuat karakteristik (sifat pembeda) perusahaan agar memiliki ciri tersendiri. ${ }^{2}$

Salah satu layanan unggulan RS Bethesda saat ini adalah unit stroke dengan jumlah kunjungan yang meningkat setiap tahunnya. Stroke Centre RS Bethesda didirikan pada tahun 1995. Struktur stroke centre terdiri dari dokter spesialis saraf, perawat dengan pelatihan khusus stroke, tim rehabilitasi medik, ahli gizi, pastoral, dan berbagai spesialis lain yang terkait. Rumah Sakit Bethesda menilai bahwa pelayanan harus terus di tingkatkan untuk memberikan pelayanan yang maksimal kepada pasien. Salah satu alat yang dapat mendukung pelayanan stroke saat ini adalah Laboratoriun Angiografi.

Untuk mewujudkan rencana pengembangan tersebut dibutuhkan perhitungan strategis karena pengadaan Laboratoriun Angiografi membutuhkan investasi besar, sumber daya cukup serta perkiraan permintaan. Analisis di awali dengan mengidentifikasi permintaan pasar mengenai kebutuhan dan kesiapan dari masyarakat. Kelayakan dari rencana investasi tersebut juga harus di analisis yang melingkupi kesiapan masyarakat dari sudut pandang aspek keuangan dan permintaan pasar.

\section{METODE PENELITIAN}

Penelitian ini adalah penelitian observasional deskriptif dengan rancangan studi kasus, merupakan penelitian dimana peneliti menggali suatu fenomena tertentu (kasus) dalam suatu waktu dan kegiatan (program, even, proses, institusi atau 
kelompok sosial) serta mengumpulkan informasi secara terinci dan mendalam dengan menggunakan berbagai prosedur pengumpulan data selama periode tertentu. Penelitian ini dilaksanakan untuk mengetahui kelayakan investasi cath lab ditinjau dari aspek keuangan.

Metode penelitian kuantitatif untuk menghitung Unit Cost pengadaan Laboratorium Angiorafi dengan metode Activity Based Costing (ABC), menganalisis kemauan dan kemampuan membayar, serta menghitung kelayakan pengadaan Laboratorium Angiorafi dengan metode keuangan seperti Pay Back Period, NPV, IRR dan Return Of Investment (ROI). ${ }^{3}$

\section{HASIL PENELITIAN}

\section{Unit Cost dan Tarif}

Pelayanan laboratorium angiografi dibagi menjadi 18 kelas. Setiap kelas mempunyai cost yang berbeda, terlebih pada unit level activity cost. Setelah mengalokasikan biaya overhead pada aktivitas, tahapan selanjutnya dalam menghitung unit cost dengan menggunakan Activity Based Costing yaitu dengan mengklasifikasikan biaya kedalam berbagai aktivitas. Pada tahap ini, tarif perunit cost driver dialokasikan kedalam produk berdasarkan kuantitas konsumsi masing-masing produk.

Tabel 1. Alokasi Biaya ke Produk Dengan Tarif Cost Driver

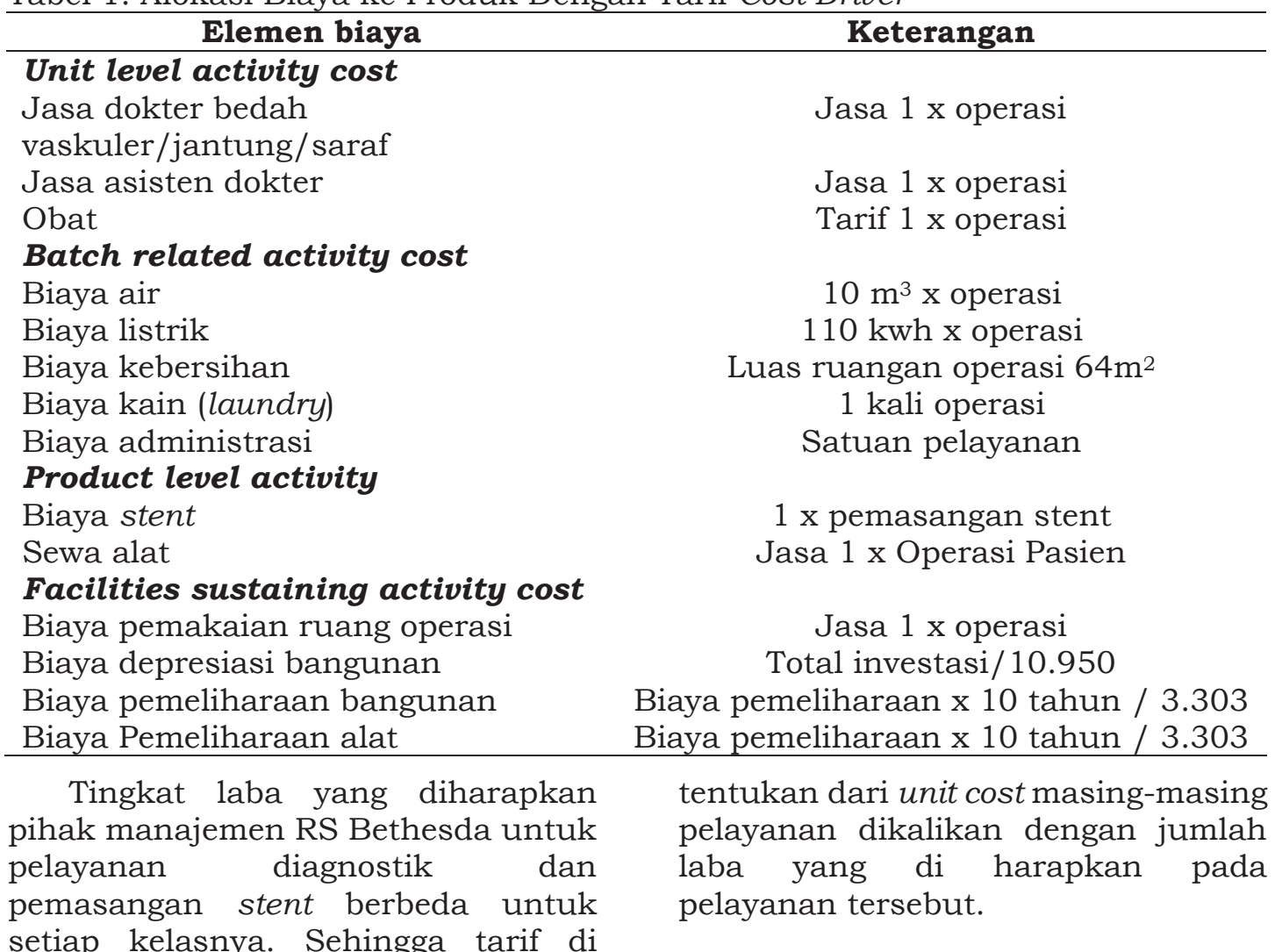


Tabel 2. Laba yang diharapkan dari masing-masing kelas

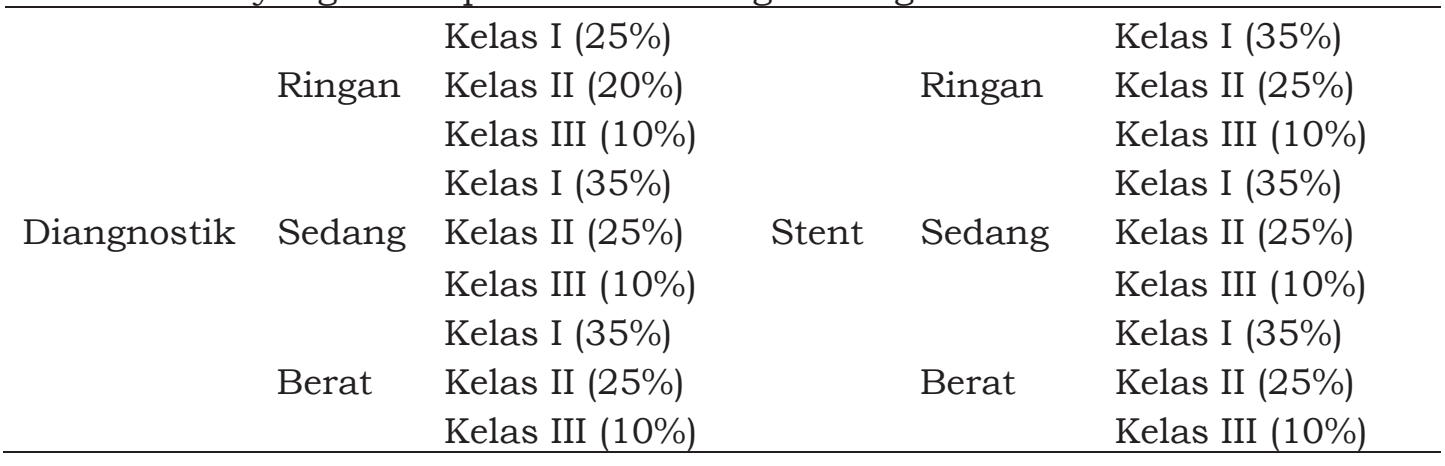

Berikut adalah unit cost dan tarif diagnostik dan pemasangan stent di RS Bethesda Yogyakarta.

Tabel 3. Unit cost, Mark Up, Tarif

\begin{tabular}{|c|c|c|c|c|c|}
\hline \multirow{9}{*}{ DIAGNOSTIK } & \multirow{4}{*}{ Ringan } & \multirow[b]{2}{*}{ Kelas I } & Unit cost & \multirow{2}{*}{$\frac{\text { Markup }}{25 \%}$} & \multirow{2}{*}{$\begin{array}{c}\text { Tarif } \\
\text { Rp. } 8.433 .993\end{array}$} \\
\hline & & & Rp 6.747 .194 & & \\
\hline & & Kelas II & Rp 6.078.694 & $20 \%$ & Rp. 7.294 .433 \\
\hline & & Kelas III & Rp 5.640.694 & $10 \%$ & Rp 6.204.763 \\
\hline & \multirow{3}{*}{ Sedang } & Kelas I & Rp 8.223.194 & $35 \%$ & $\operatorname{Rp} 11.101 .312$ \\
\hline & & Kelas II & Rp 6.728.194 & $25 \%$ & Rp 8.410.243 \\
\hline & & Kelas III & $\mathrm{Rp} 6.254 .194$ & $10 \%$ & $\mathrm{Rp} 6.879 .613$ \\
\hline & \multirow[t]{2}{*}{ Berat } & Kelas II & Rp 8.538.694 & $25 \%$ & Rp 10.673.368 \\
\hline & & Kelas III & Rp 7.394.194 & $10 \%$ & Rp 8.133.613 \\
\hline & & & Unit cost & Mark up & Tarif \\
\hline \multirow{9}{*}{ STENT } & \multirow{3}{*}{ Ringan } & Kelas I & Rp 20.693.194 & $35 \%$ & Rp 27.935.81 \\
\hline & & Kelas II & Rp 20.038.194 & $25 \%$ & $\operatorname{Rp} 25.047 .74$ \\
\hline & & Kelas III & Rp 19.540.694 & $10 \%$ & $\operatorname{Rp} 21.494 .76$ \\
\hline & \multirow{3}{*}{ Sedang } & Kelas I & Rp 24.639.694 & $35 \%$ & Rp 33.263 .58 \\
\hline & & Kelas II & Rp 23.448.694 & $25 \%$ & $\operatorname{Rp} 29.310 .86$ \\
\hline & & Kelas III & Rp 22.494.194 & $10 \%$ & $\operatorname{Rp} 24.743 .61$ \\
\hline & \multirow{3}{*}{ Berat } & Kelas I & Rp 26.553.194 & $35 \%$ & $\mathrm{Rp} \quad 35.846 .81$ \\
\hline & & Kelas II & Rp 24.722.194 & $25 \%$ & Rp 30.902 .74 \\
\hline & & Kelas III & Rp 23.744.194 & $10 \%$ & Rp 26.118 .61 \\
\hline
\end{tabular}

2. Kemampuan Membayar (ATP) dan Kemauan Membayar (WTP)

Dalam menetapkan tarif, salah satu aspek yang perlu dipertimbangkan adalah kemampuan membayar masyarakat. Menghitung kemampuan membayar masyarakat pada penelitian ini. a. Karakteristik Responden

Untuk mengukur kemampuan dan kemauan membayar biaya pelayanan Laboratorium Angiografi di RS Bethesda, dilakukan pengumpulan data dengan menggunakan kuesioner kepada 265 responden. 
Tabel 4. Distribusi Responden Berdasarkan Karakteristik

\begin{tabular}{|c|c|c|}
\hline No & Karakteristik responden $(n=265)$ & Persentase \% \\
\hline 1 & $\begin{array}{l}\text { Jenis Kelamin } \\
\text { - Laki-Laki } \\
\text { - Perempuan }\end{array}$ & $\begin{array}{l}51 \% \\
49 \%\end{array}$ \\
\hline . & $\begin{array}{l}\text { Umur } \\
-20-35 \text { tahun } \\
-36-50 \text { tahun } \\
-50<\text { tahun }\end{array}$ & $\begin{array}{l}23 \% \\
23 \% \\
54 \%\end{array}$ \\
\hline 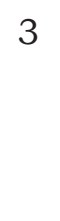 & $\begin{array}{l}\text { Pekerjaan } \\
\text { - public sector } \\
\text { - private sector } \\
\text { - pensiunan } \\
\text { - lain lain }\end{array}$ & $\begin{array}{l}19 \% \\
40 \% \\
18 \% \\
23 \%\end{array}$ \\
\hline 4 & $\begin{array}{l}\text { Tempat tinggal } \\
\text { DIY } \\
\text { - Kota jogja } \\
\text { - Sleman } \\
\text { - Bantul } \\
\text { - Gunung kidul } \\
\text { - Kulonprogo } \\
\text { Jawa Tengah } \\
\text { Jawa Timur } \\
\text { Provinsi Lain }\end{array}$ & $\begin{array}{c}26 \% \\
27 \% \\
14 \% \\
8 \% \\
8 \% \\
12 \% \\
3 \% \\
2 \%\end{array}$ \\
\hline 5 & $\begin{array}{l}\text { Pendidikan } \\
\text { SD - SMA } \\
\text { Perguruan Tinggi } \\
\text { Jumlah anggota keluarga } \\
-<2 \\
-2-5 \\
->5\end{array}$ & $\begin{array}{l}40 \% \\
60 \% \\
\\
2 \% \\
80 \% \\
18 \%\end{array}$ \\
\hline & $\begin{array}{l}\text { Pendapatan keluarga } \\
<1.000 .000 \\
1.000 .000-5.000 .0000 \\
5.000 .000-10.000 .000 \\
10.000 .000-20.000 .000 \\
20.000 .000-50.000 .000 \\
>50.000 .000\end{array}$ & $\begin{array}{c}1 \% \\
43 \% \\
37 \% \\
13 \% \\
4 \% \\
2 \%\end{array}$ \\
\hline
\end{tabular}

Tabel menunjukkan bahwa jumlah responden laki laki dan perempuan hampir sama. Pasien dengan rentang usia 50 tahun lebih sebanyak 54\%, 40\% responden bekerja di privat sector seperti pedagang, petani, karyawan swasta dan lain lain. b. Kemampuan Membayar (Ability to Pay)

Kemampuan membayar (Ability to pay) biaya pelayanan kesehatan dapat diukur dari keseluruhan biaya yang dikeluarkan untuk keperluan di luar kebutuhan dasar4. Dari hasil penelitian diketahui jumlah pendapatan rata-rata keluarga responden perbulan adalah sebagi berikut. 
Tabel 5. Jumlah Pendapatan Keluarga Perbulan

\begin{tabular}{ccc}
\hline Jumlah pendapatan (Rp) & n (265) & Persentase \% \\
\hline$>1.000 .000$ & 4 & $1 \%$ \\
$1.000 .000-5.000 .0000$ & 113 & $43 \%$ \\
$5.000 .000-10.000 .000$ & 98 & $37 \%$ \\
$10.000 .000-20.000 .000$ & 35 & $1 \%$ \\
$20.000 .000-50.000 .000$ & 10 & $4 \%$ \\
$<50.000 .000$ & 5 & $2 \%$ \\
\hline
\end{tabular}

Dari data 265 responden didapatkan rata- rata pendapatan perbulan adalah sebesar Rp.9.306.792,- dan pengeluaran untuk kebutuhan pangan rata-rata perbulan adalah sebesar Rp.1.930.000,-. Tingkat kemampuan membayar dinilai dari 10\% dissposible income (pendapatan - pengeluaran pangan), sehingga didapatkan hasil ATP Rp. 737.679,-

c. Kemauan Membayar (WTP)

Kemauan membayar dalam penelitian ini adalah kesediaan responden membayar biaya pelayanan kesehatan. Pengukuran kemauan membayar tarif pelayanan Laboratorium Angiografi di RS Bethesda Yogyakarta dilakukan melalui wawancara langsung kepada 265 responden.

Hasil dari kemauan membayar akan mempengaruhi tingkat pemanfaatan layanan dan sebagai masukan kepada pembuat kebijakan dalam penetapan tarif. Kemauan membayar dapat dikatakan sebagai konsep yang sering di gunakan untuk memberikan informasi pada pengambilan kebijakan di sektor kesehatan $^{5}$. Dari hasil pengumpulan data kemauan membayar responden dapat dirinci sebagai berikut.

Tabel 6. Kemauan Membayar Responden

\begin{tabular}{ccc}
$\begin{array}{c}\text { Kemauan Membayar Tarif Pelayanan } \\
\text { Laboratorium Angiografi }\end{array}$ & n (265) & \% \\
Rp. 0,- & 28 & $11 \%$ \\
Rp. $<10.000 .000$ & 12 & $4 \%$ \\
Rp. $10.000 .001-20.000 .000$ & 21 & $8 \%$ \\
Rp. $20.000 .000-30.000 .000$ & 15 & $6 \%$ \\
Rp. $30.000 .001-40.000 .000$ & 57 & $21 \%$ \\
Rp. $40.000 .001-50.000 .000$ & 28 & $11 \%$ \\
Rp. $50.000 .001-60.000 .000$ & 17 & $6 \%$ \\
Rp. > 60.000.000 & 87 & $33 \%$ \\
Jumlah & 265 & $100 \%$ \\
\hline
\end{tabular}

\section{Estimasi kelayakan investasi Laboratorium Angiografi}

Analisis dari segi keuangan dimaksudkan untuk mendapatkan paparan lebih baik mengenai kelayakan investasi Laboratorium Angiografi RS Bethesda dari sisi keuangan. Analisis keuangan ini menggunakan aliran kas tunai yang menggunakan aliran kas tunai yang terdiskonto, yang mempertimbangkan pendapatan dari analisis tingkat pertumbuhan pasar. Indikator kelayakan investasi yang digunakan 
adalah Payback Period, Net Present Value (NPV), Internal Rate of Return (IRR) dan Return On Invesment (ROI). 6

Dalam menghitung proyeksi aliran kas tunai pada studi kelayakan ini dipergunakan beberapa asumsi. Adapun asumsi-asumsi tersebut adalah (a) Tarif yang digunakan adalah tarif yang telah di perhitungkan sebelumnya. (b) Jumlah pasien diagnostik pada tahun pertama 156 dan 52 untuk pasien dengan pemasangan stent. (c) Peningkatan tarif sebesar 7 persen setiap tahunnya selama umur proyeksi. (d) Proyeksi aliran kas tunai selama 10 tahun. (e) Depresiasi peralatan medis selama 10 tahun. (f) Depresiasi gedung selama 30 tahun. a. Investasi dihitung sekaligus pada tahun ke nol.

Invetasi yang akan dilakukan oleh RS Bethesda meliputi bangunan dan investasi alat. Investasi ruangan sebesar Rp.200.000.000,00 dan investasi Laboratoriun Angiografi sebesar Rp.11.888.000.000,00. Investasi sebesar Rp.11.888.000.000,- diketahui dari nilai tender pengadaan Laboratorium Angiografi di rumah sakit Karyadi, Semarang tahun 2015.

\section{a. Payback Period (PP)}

Diketahui total investasi adalah sebesar Rp.12.088.000.000,00 jumah tersebut dapat dikembalikan dalam jangka waktu 4 tahun 11 bulan. Seperti pada tabel dibawah ini.

Tabel 7. Payback period

\begin{tabular}{|c|c|c|}
\hline tahun 0 & $\operatorname{Rp}(12.088 .000 .000)$ & Sisa Invetasi \\
\hline 1 & Rp 2.352.766.094 & Rp (9.735.233.906) \\
\hline 2 & Rp 2.558.251.133 & Rp (7.176.982.773) \\
\hline 3 & Rp 3.056.310.990 & $\operatorname{Rp}(4.120 .671 .784)$ \\
\hline 4 & Rp 3.609.469.062 & $\operatorname{Rp}(511.202 .722)$ \\
\hline 5 & Rp 4.439.411.168 & 0,9 \\
\hline 6 & Rp 5.472.002.757 & \\
\hline 7 & Rp 6.761.282.350 & \\
\hline 8 & Rp 7.596.204.531 & \\
\hline 9 & Rp 8.520.597.462 & \\
\hline \multirow[t]{3}{*}{10} & Rp 9.280.034.932 & \\
\hline & payback period & 4,9 tahun \\
\hline & payback period & 4 tahun 11 bulan \\
\hline
\end{tabular}

Jangka waktu pengembalian modal yang diharapkan manajemen rumah sakit Bethesda selama lima tahun. Analisis menggunakan nilai Payback Period menunjukkan waku pengembalian modal selama 4 tahun 11 bulan. Dapat disimpulkan dari perhitungan analisis menggunakan Payback Period kelayakan Investasi Laboratorium Angiografi layak dilakukan.

\section{b. NPV}

Merupakan selisih antara nilai investasi saat ini dibandingkan dengan aliran kas bersih tunai (operasional dan terminal value) masa yang akan datang yang dibawa kesaat ini dengan menggunakan faktor diskonto. ${ }^{7}$ NPV dari hasil perhitungan dengan menggukan komputer program excel, dari kelayakan investasi Laboratoriun Angiografi adalah sebesar Rp.23.519.363.711,-. 


\section{c. IRR}

Merupakan tingkat pengembalian yang menyebabkan nilai bersih investasi saat ini sama dengan nol. ${ }^{7}$ Hasil perhitugan IRR dengan menggunakan program excel adalah sebesar $29 \%$.

\section{d. ROI (Return On Invstment)}

Return On Invstment yaitu suatu cara untuk mengukur seberapa banyak laba bersih yang bisa diperoleh dari seluruh kekayaan yang dimiliki8. Hasil perhitungan ROI dengan program excel adalah sebesar $120 \%$.

\section{PEMBAHASAN}

\section{Unit Cost dan Tarif}

Hasil perhitungan tarif pelayanan Laboratorium Angiografi dengan menggunakan metode Activity Based
Costing (ABC) dalam penelitian ini mengelompokan unit cost dan tarif pelayanan diagnostik dan pemasangan Stent kedalam 18 Kelas. Penentuan unit cost di ambil dari data keuangan RS Bethesda, data keuangan rumah sakit lain, serta beberapa asumsi yang sekiranya tepat untuk unit cost pelayanan Laboratorium Angiografi di rumah sakit Bethesda Yogyakarta.

Pada tahun pertama RS Bethesda memperkirakan dalam 1 minggu bisa menangani tiga pasien diagnostik dan satu pasien stent. Dengan harapan terjadi peningkatan jumlah pasien setiap tahunnya. Jika biaya balik modal di asumsikan selama sepuluh tahun, maka jumlah pasien RS Bethesda selama sepuluh tahun tersebut adalah:

Tabel 8. Estimasi Pertumbuhan Pasien

\begin{tabular}{ccccc}
\hline Tahun & pertumbuhan & Diagnostik & Stent & Jumlah \\
\hline 1 & $0 \%$ & 156 & 52 & 208 \\
2 & $5 \%$ & 164 & 55 & 218 \\
3 & $10 \%$ & 180 & 60 & 240 \\
4 & $10 \%$ & 198 & 66 & 264 \\
5 & $15 \%$ & 228 & 76 & 304 \\
6 & $15 \%$ & 262 & 87 & 349 \\
7 & $15 \%$ & 301 & 100 & 402 \\
8 & $5 \%$ & 317 & 106 & 422 \\
9 & $5 \%$ & 332 & 111 & 443 \\
10 & $2 \%$ & 339 & 113 & 452 \\
& Jumlah & 2477 & 826 & 3303 \\
\hline
\end{tabular}

Pertumbuhan jumlah pasien di perkirakan oleh dokter spesialis, dengan mempertimbangkan tren, pesaing, pasar, serta perkembangan teknologi terbaru. Pesaing atau kompetitor perlu dipertimbangkan dalam rangka penentuan strategi tarif. Untuk dapat mengidentifikasi nilai dari karakteristik pelayanan dapat diidentifikasi melalui ability to pay dan willingness to pay dari konsumen. Terdapat tiga rumah sakit yang telah terlebih dahulu mempunyai pelayanan Laboratoriun Angiografi di DIY, yaitu: 
Tabe1 9. Perbandingan Tarif Dengan Rumah Sakit Lain

\begin{tabular}{ccc}
\hline Rumah Sakit & Tarif diagnostik & Tarif PTCA \\
\hline RS Umum Pusat milik Pemerintah & $8-11$ juta & $25-30$ juta \\
RS swasta milik Yayasan Keagamaan & \pm 18 juta & \pm 50 juta \\
RS milik Angkatan Udara & \pm 15 juta & \pm 35 juta \\
\hline
\end{tabular}

Dari informasi tarif ketiga rumah sakit tersebut, sebagai pesaing baru RS Bethesda berupaya untuk menarik calon pasien dengan menetapkan tariff yang lebih rendah. Markup atau keutungan yang di ambil lebih rendah dari rumah sakit pesaing. Kenaikan tarif diasumsikan tujuh persen setiap tahunnya. Angka ini didasarkan pada suku bunga deposito bank dalam satu tahun yaitu sebesar $7,13 \%$.
Selain tarif pesaing, RS Bethesda juga memperhitungkan tarif rumah sakit jika pasien memakai asuransi BPJS. Dari hasil analisis, pembiayaan dari BPJS masih lebih tinggi dari tarif rumah sakit Bethesda. Berikut perbandingan tarif rumah sakit dengan INA-CBGs BPJS regional 1, Rumah sakit tipe B.

Tabel 10. Perbandingan Tarif Rumah Sakit Dengan INA-CBGs

\begin{tabular}{|c|c|c|c|c|}
\hline \multirow{10}{*}{ DIAGNOSTIK } & & Kelas & Tarif RS (Rp.) & BPJS (Rp.) \\
\hline & \multirow{3}{*}{ Ringan } & Kelas I & 8.433 .993 & 8.614 .350 \\
\hline & & Kelas II & 7.294 .433 & 7.383 .728 \\
\hline & & Kelas III & 6.204 .763 & 6.153 .107 \\
\hline & \multirow{3}{*}{ Sedang } & Kelas I & 11.101 .312 & 16.202 .961 \\
\hline & & Kelas II & 8.410 .243 & 13.888 .252 \\
\hline & & Kelas III & 6.879 .613 & 11.753 .543 \\
\hline & \multirow{3}{*}{ Berat } & Kelas I & 13.999 .087 & 25.365 .296 \\
\hline & & Kelas II & 10.673 .368 & 21.742 .222 \\
\hline & & Kelas III & 8.133 .613 & 18.118 .519 \\
\hline \multirow{9}{*}{ STENT } & \multirow{3}{*}{ Ringan } & Kelas I & 27.935 .812 & 31.939 .466 \\
\hline & & Kelas II & 25.047 .743 & 27.376 .686 \\
\hline & & Kelas III & 21.494 .763 & 22.813 .905 \\
\hline & \multirow{3}{*}{ Sedang } & Kelas I & 33.263 .587 & 41.201 .912 \\
\hline & & Kelas II & 29.310 .868 & 35.315 .924 \\
\hline & & Kelas III & 24.743 .613 & 29.429 .937 \\
\hline & \multirow{3}{*}{ Berat } & Kelas I & 35.846 .812 & 50.783 .752 \\
\hline & & Kelas II & 30.902 .743 & 43.528 .930 \\
\hline & & Kelas III & 26.118 .613 & 36.274 .108 \\
\hline
\end{tabular}

Pada perbandingan tarif diagnostik ringan Kelas III dengan tarif INACBGs, tarif rumah sakit sedikit lebih tinggi, namun rumah sakit dapat melakukan subsidi silang terhadap perbandingan tarif lainnya, sehingga kekurangan ini dapat diatasi.

\section{Ability to Pay (ATP) dan Willingness to Pay (WTP) Pelayanan Laboratorium Angiografi di RS Bethesda Yogyakarta. \\ Terdapat dua metode pengukuran} kemampuan dan kemauan membayar masyarakat untuk pelayanan kesehatan, yaitu.9: (a) Dengan mengobservasi dan membuat contoh pemanfaatan pemeliharaan kesehatan yang lalu, pembelanjaan dan penanggapan terhadap harga. (b) Dengan bertanya pada masyarakat secara langsung berapa banyak mereka bersedia dan mampu untuk membayar produk pelayanan kesehatan.

Penelitian ini menggunakan metode yang kedua, yaitu dengan bertanya secara langsung kepada responden, seberapa banyak mereka 
mampu dan mau mengeluarkan dana untuk suatu pelayanan kesehatan. Kuesioner yang digunakan dalam penelitian ini, telah divalidasi dan pernah digunakan dalam penelitian terdahulu.

Responden yang dipilih untuk dilakukan wawancara mengenai kemampuan dan kemauan membayar pelayanan Laboratoriun Angiografi adalah pasien/keluarga pasien poliklinik jantung dan saraf RS Bethesda Yogyakarta.

Dari hasil penelitian, rata-rata umur responden yang dilakukan wawancara lebih dari 50 tahun. Hal ini menunjukkan bahwa responden yang berumur 50 tahun lebih memiliki kebutuhan yang tinggi terhadap pelayanan Laboratoriun Angiografi di RS Bethesda Yogyakarta.

Hasil penelitian menunjukkan kemampuan rata-rata pasien RS Bethesda Yogyakarta untuk membayar tarif pelayanan Laboratoriun Angiografi sebesar Rp.737.679,- kemampuan membayar masyarakat ini dihitung dari jumlah rata-rata penghasilan dikurangi ratarata pengeluaran pangan dikalikan $10 \%$ (dissposible income). Dapat disimpulkan bahwa kemampuan masyarakat dalam membayar biaya pelayanan Laboratoriun Angiografi masih sangat jauh dari rata-rata tarif pelayanan Laboratoriun Angiografi yang ditetapkan oleh beberapa rumah sakit di Jogjakarta.

Kemauan masyarakat untuk menggunakan pelayanan Laboratoriun Angiografi cukup tinggi, $33 \%$ dari total responden bahkan bersedia membayar berapapun jika disarankan untuk memakai pelayanan ini. Kemauan yang cukup tinggi ini sayangnya belum didukung oleh kemampuan yang tinggi pula.

Pemerintah, melalui program BPJS memfasilitasi masyarakat yang membutuhkan pelayanan Laboratoriun Angiografi. Penggantian biaya terhadap penyedia pelayanan kesehatan diatur oleh PerMenKes No. 69 tahun 2013, tentang Standar Tarif Pelayanan Kesehatan Pada Fasilitas Kesehatan Tingkat Pertama dan Fasilitas Kesehatan Tingkat Lanjutan Dalam Penyelenggaraan Program Jaminan Kesehatan, sehingga masyarakat yang tidak mampu dapat merasakan pelayanan Laboratoriun Angiografi dengan bantuan BPJS.

Responden yang menggunakan BPJS sebagai asuransi kesehatan cukup tinggi dapat dilihat pada tabel berikut.

Tabel 11. Asuransi yang digunakan Responden

\begin{tabular}{cccc}
\hline No & Asuransi & n (265) & Persentase \% \\
\hline 1 & BPJS & 228 orang & $86 \%$ \\
2 & Mandiri (tidak punya asuransi) & 22 orang & $8 \%$ \\
3 & Asuransi Lain & 15 orang & $6 \%$ \\
\hline
\end{tabular}

\section{Kelayakan investasi Laboratoriun Angiografi RS Bethesda Yogyakarta.}

a. Payback Period

Metode analisis payback period bertujuan untuk mengetahui seberapa lama (periode) investasi akan dapat dikembalikan saat terjadinya kondisi break even-point (jumlah arus kas masuk sama dengan jumlah arus kas keluar). Analisis payback period dihitung dengan cara menghitung waktu yang diperlukan pada saat total arus kas masuk sama dengan total arus kas keluar.

Rumah sakit menginginkan waktu balik modal paling lama adalah lima tahun. Pada perhitungan payback period (PP) tahun ke lima menunjukkan nilai yang positif. Untuk mendapatkan Payback Period digunakan rumus interpolasi, 
menghasilkan nilai PP sebesar 4,9 tahun. Artinya waktu pengembalian yang dibutuhkan pada penanaman modal investasi Laboratorium Angiografi adalah selama 4 tahun 11 bulan. Waktu ini lebih cepat dari waktu yang di targetkan oleh manajemen rumah sakit.

b. NPV

Perhitungan dalam analisis keuangan menggunakan asumsi discount factor sebesar 14\% dengan dasar suku bunga bank konvensional yang berlaku. Dasar suku bunga bank yang menjadi pedoman rumah sakit adalah suku bunga bank BRI sebesar $7,13 \%$ /tahun. Rumah sakit menginginkan nilai yang lebih besar dari suku bunga tersebut sehingga di targetkan sebesar 14\%. Dalam perhitungan nilai masa sekarang atau yang dikenal dengan Net Present Value (NPV) didapat nilai sebesar Rp.23.569.363.711,- Nilai tersebut merupakan hasil perkalian net cash flow dengan discount factor. Sebagai tolak ukur profitabilitas dari suatu proyek, dapat dilihat dari hasil NPV yang menunjukkan hasil yang positif. Karena nilai NPV yang didapat dari hasil perhitungan > 0 maka dapat disimpulkan bahwa proyek tersebut layak (feasible) untuk dilaksanakan.

c. IRR

Internal Rate of Return dipergunakan untuk mengevaluasi profitabilitas rencana investasi dengan menggunakan nilai waktu sekarang. Dari hasil perhitungan IRR dengan rumus excel, maka nilai IRR yang didapatkan adalah suku bunga sebesar $14 \%$ artinya pelaksanaan investasi Laboratoriun Angiografi akan menghasilkan NPV positif sampai dengan maksimal pada suku bunga 29\%. Karena nilai IRR lebih tinggi dari suku bunga yang ditargetkan yaitu 14\% dan nilai NPV positif, maka disimpulkan bahwa pelaksanaan investasi layak dilaksanakan.

\section{d. ROI}

Return On Investment (ROI), sering juga disebut dengan Return on Total Asset, merupakan pengukuran kemampuan perusahaan secara keseluruhan aktiva yang tersedia di dalam perusahaan. Semakin tinggi rasio, semakin baik keadaan suatu perusahaan.

Return of Investment (ROI) dari pelayanan tarif Laboratoriun Angiografi RS Bethesda Yogyakarta menghasilkan tingkat pengembalian laba sebesar $120 \%$. Angka ini didapatkan dari keuntungan bersih program dikalikan estimasi pasien dalam jangka waktu 10 tahun (3.303 pasien), dibagi dengan modal Rp.12.088.000.000,-. Keuntungan bersih dihitung dari persentasi biaya modal setiap Kelas.

Kemampuan pelayanan Laboratoriun Angiografi di RS Bethesda untuk mengembalikan modal adalah sebesar $120 \%$. Hasil ini dapat dijadikan salah satu pertimbangan untuk pihak manajemen dalam mengambil keputusan investasi Laboratoriun Angiografi di RS Bethesda Yogyakarta.

\section{KESIMPULAN}

Dari hasil penelitian Analisis keuangan terhadap kelayakan Investasi Laboratorium Angiografi di Rumah Sakit Bethesda Yogyakarta, dapat disimpulkan bahwa investasi ini layak di lakukan dari segi keuangan.

\section{SARAN}

1. Perlu dilakukan penelitian lebih lanjut terutama pada aspek lainnya, seperti aspek pemasaran, sumber daya manusia, lingkungan sosial dan lainnya. sehingga makin meyakinkan untuk investasi Laboratorium Angiografi di RS Bethesda.

2. Perhitungan unit cost dan tarif dapat dijadikan masukan bagi bagian keuangan di rumah sakit, 
dengan tetap memperhitungkan aktivitas dan sumber daya yang sesuai dengan kebutuhan Rumah Sakit Bethesda.

3. Rumah sakit perlu mempertimbangkan tarif layanan Laboratorium Angiografi terhadap Asuransi yang di pakai oleh pasien Rumah Sakit Bethesda Yogyakarta.

4. Rumah sakit Bethesda perlu mempersiapkan strategi pemasaran pelayanan Laboratorium angiografi, karena di Provinsi DIY sudah ada tiga rumah sakit yang terlebih dahulu bersaing dalam pelayanan ini.

\section{DAFTAR PUSTAKA}

1. Trisnantoro L. Aspek strategis dalam Manajemen Rumah Sakit. Penerbit Andi: Yogyakarta. 2005.

2. Sunarto. Pengantar Manajemen Pemasaran. Cet. 1. Ust Press: Yogyakarta. 2006.

3. DeFusco, Richard A, et all. Quantitative Investment Analysis $2^{\text {nd }}$ Edition. John Wiley \& Sons, Inc: New Jersey. 2007.

4. Husnan dan Muhammad. Study Kelayakan Proyek (Edisi 4). UPP YKPN: Yogyakarta. 2005.

5. Kongstvedl, R. Pokok-Pokok Pengelolaan Usaha Pelayanan Kesehatan. TGC: Jakarta. 2000.

6. Hendra, Yos. Studi Kelayakan Investasi Pembangunan RS Sehat Bahagia Pekan Baru. Thesis: UGM. 2013.

7. Harming, Murdifin. Salam Basalamah. Studi kelayakan investasi proyek dan bisnis. PPM: Jakarta. 2003.

8. Buzachero Victor, et al. Measuring ROI IN Health Care: Tools and Techniques to Meansur the Impact and ROI In Health Care. Improvement Projects and Program. Mc Graw Hilll Education: USA. 2013.

9. Russell S, Fox-Rushby J, Arhin D. Willingness and ability to pay for health care: a selection of methods and issues. 1995. 
